\title{
Non-allergic rhinitis: a case report and review
}

\author{
Cyrus H Nozad ${ }^{1 *}$, L Madison Michael ${ }^{2,3}$, D Betty Lew ${ }^{1}$, Christie F Michael ${ }^{1}$
}

\begin{abstract}
Rhinitis is characterized by rhinorrhea, sneezing, nasal congestion, nasal itch and/or postnasal drip. Often the first step in arriving at a diagnosis is to exclude or diagnose sensitivity to inhalant allergens. Non-allergic rhinitis (NAR) comprises multiple distinct conditions that may even co-exist with allergic rhinitis (AR). They may differ in their presentation and treatment. As well, the pathogenesis of NAR is not clearly elucidated and likely varied. There are many conditions that can have similar presentations to NAR or AR, including nasal polyps, anatomical/mechanical factors, autoimmune diseases, metabolic conditions, genetic conditions and immunodeficiency. Here we present a case of a rare condition initially diagnosed and treated as typical allergic rhinitis vs. vasomotor rhinitis, but found to be something much more serious. This case illustrates the importance of maintaining an appropriate differential diagnosis for a complaint routinely seen as mundane. The case presentation is followed by a review of the potential causes and pathogenesis of NAR.
\end{abstract}

\section{Introduction}

The term rhinitis can be used to describe many distinct entities with varying pathogeneses, despite similar presentations. Generally, rhinitis is considered allergic if significant inhalant allergy is diagnosed and is considered non-allergic when symptomatology is perennial or periodic and not IgE mediated. Thus non-allergic rhinitis (NAR) comprises a mixed bag of conditions ranging from vasomotor rhinitis (VMR) to hormonally induced rhinitis.

Overall, rhinitis results in significant cost to the world population. In 2002, the direct and indirect costs for allergic rhinitis (AR) were estimated to be $\$ 7.3$ billion and $\$ 4.28$ billion, respectively [1]. Given that an estimated 1 in 3 patients with rhinitis are diagnosed with NAR, with 19 million people in the United States alone, it is reasonable to conclude that NAR also results in a significant economic burden [2-4].

NAR is a condition primarily seen in adulthood with $70 \%$ of cases developing after the age of 20 . There is a greater prevalence among females compared to males $[5,6]$, and the overall prevalence of NAR in industrialized countries has ranged from $20-40 \%$ [7]. The following case presentation is an example of a patient with typical NAR symptoms who fits the epidemiological profile, but who presented atypically, failed to respond

\footnotetext{
*Correspondence: cnozad@uthsc.edu

'Division of Clinical Immunology, University of Tennessee Health Science Center, 50 North Dunlap St, RM 401 WPT, Memphis, TN, USA
}

to standard therapy and was subsequently found to have a much more serious underlying condition.

\section{Case Report}

A 52 year old African American female presented to our outpatient allergy clinic with a chief complaint of profuse "runny nose" for 1 week. She initially attributed the rhinorrhea to prolonged moth ball exposure in her small office space. Prior to her visit she had been seen by her primary care provider and in the emergency department. Both treated her for allergic rhinitis vs. vasomotor rhinitis with intranasal corticosteroids and oral antihistamines. She also complained of a diffuse headache, imbalance, cough and right ear fullness. She denied any history of previous rhinitis symptoms, eye symptoms or sneezing. Her past medical history was significant for hypertension, hypercholesterolemia, diabetes mellitus (poorly controlled) and excision of a benign scalp lesion at age 18. Family history was significant for a father and eight siblings with allergic rhinitis and one brother with asthma. Her social history was significant for pet and tobacco smoke exposure. She denied any illicit drug use. Review of systems was negative for trauma, fevers, chills, weight loss, night sweats, shortness of breath, chest pain, nausea, vomiting or diarrhea; and positive for, diffuse headaches, unsteadiness and a cough productive of clear sputum that was worse when supine.

On physical exam her vital signs were: BP 172/86, P 89, R 18, T 36.2 C, W 95 kg. Generally, she presented 
to us holding a rag over her nose, coughing, but not in distress. She had a normocephalic/atraumatic head, tympanic membranes were clear, and conjunctivae were clear. She had copious clear nasal discharge from the right naris with a continual drip. The nasal mucosa was otherwise moist and mildly erythematous; with slightly atrophic turbinates. There was no chest deformity. The lungs were clear to auscultation without wheezes, rubs or rhonchi. Cardiovascularly, she had a regular rate and rhythm without murmurs, rubs or gallops. The abdomen was soft, non-tender/non-distended and no masses were palpated. Skin exam revealed no lesions. Extremity examination did not reveal any cyanosis, clubbing or edema. Lastly she had no enlarged cervical lymph nodes.

A sample of her nasal rhinorrhea was sent to the lab to analyze for beta-2 transferrin. She was then sent for a stat CT scan of her head. The patient's rhinorrhea sample was positive for beta- 2 transferrin, consistent with a cerebrospinal fluid leak (CSF). The CT scan showed mucosal thickening of the ethmoid sinuses and nasal septal deviation, but no intracranial findings to explain CSF leak. Consultation with Neurosurgery and ENT were made. When the leak failed to resolve spontaneously, she underwent a CT cisternogram to localize the leak. A defect was identified in the cribriform plate bilaterally with CSF extension into several bilateral ethmoid air cells, Figure 1. She underwent an endoscopic ethmoidotomy and repair of her cerebrospinal fluid leak by ENT. After surgery, neurosurgery placed a lumbar drain for 72 hours to divert the CSF in order for the repair to properly seal. Repeat CT cisternogram 1 month later no longer showed evidence of CSF leak.

\section{Cerebrospinal Rhinorrhea Etiology, Diagnosis and Treatment}

CSF is produced in the choroid plexus at a rate of $350-500 \mathrm{ml}$ per day. The total adult volume is $90-150$ $\mathrm{ml}$. This volume is turned over 3-5 times per day via continual absorption by the arachnoid villa. The etiologies of CSF leak include accidental trauma from a closed head injury (44\%), surgical trauma (29\%), tumors (22\%), congenital skull base deformities (rare), and spontaneous leak (3-4\%, but in some series are as high as 15-20\%) due to increased intracranial pressure (ICP) [8-10], Figure 2.

As in our case, the diagnosis starts with identification of the rhinorrhea as CSF. The fluid is analyzed for beta2 transferrin, which is formed by the conversion of beta- 1 transferrin into beta- 2 transferrin by cerebral neuraminidase [11]. Beta-2 transferrin is only found in the CSF, vitreous humor of the eye and perilymph. Next, the site of the leak must be identified. A high resolution CT scan of the head can evaluate the paranasal sinuses as well as the skull base. Adding intrathecal

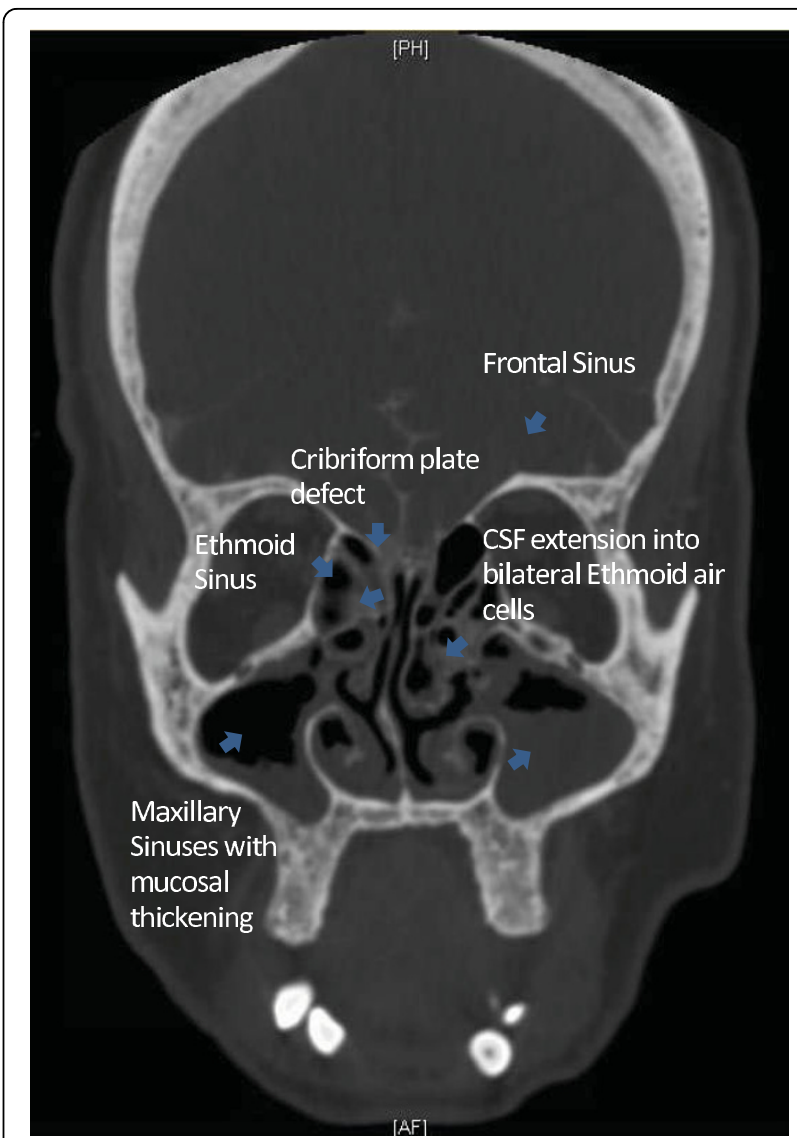

Figure 1 Preoperative CT scan of the head. A preoperative CT scan of the head with intrathecal contrast was done to localize the CSF leak. The frontal view is shown here. The scan shows a defect in the cribriform plate with confluent CSF extension into several bilateral ethmoid air cells, evidenced by the higher intensity signal of the contrast. Secondarily, there is mucosal thickening in the ethmoid and maxillary sinuses.

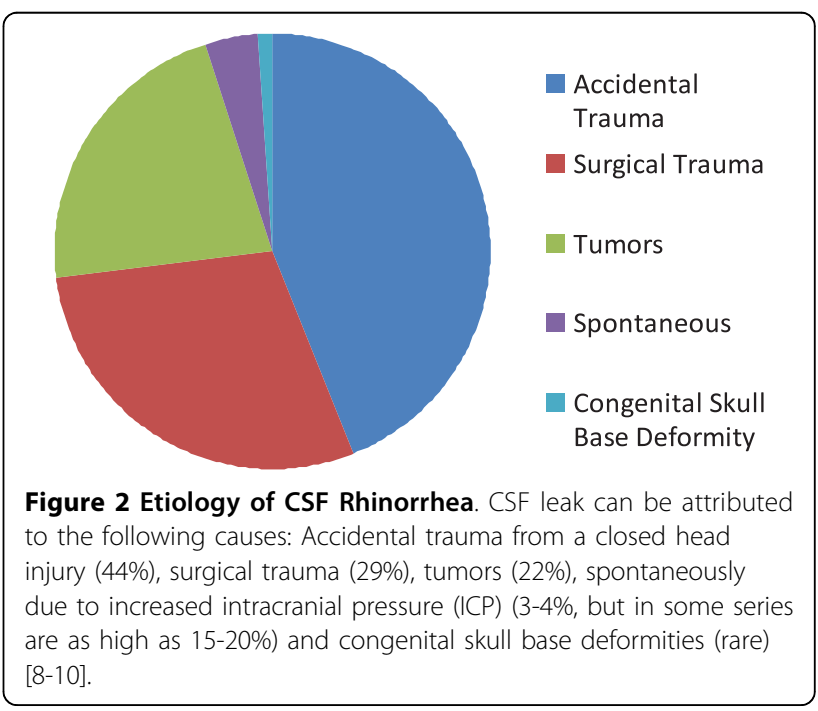


contrast can allow for better localization of a leak. If a patient has an inactive or intermittent leak, they may have a negative CT scan. CT scan has a sensitivity ranging from 48 to $96 \%$ [11,12]. Magnetic resonance cisternography is another method of localization of CSF leaks and has a sensitivity of $92-100 \%$. MRI is also used as an adjunct test for further characterization of meningoencephalocele, if present [13].

Patients with a spontaneous CSF leak, due to an associated increase in intracranial pressure can have characteristic findings. These findings are, a broadly thinned and attenuated skull base, dehiscence of the ethmoid roof, arachnoid pits (from bony impressions from arachnoid villa), pneumatization of the lateral sphenoid sinus recess and meningoencephalocele formation [14-16]. The most common sites for a leak in these patients include, the lateral recess of the sphenoid sinus and the ethmoid roof or cribriform [11].

Treatment can consist of a traditional open craniotomy with repair of the defect. This approach has a success rate of $70-80 \%[17,18]$. Newer endoscopic repairs have shown greater success, with rates $>90 \%$ and avoid the morbidity associated with craniotomy [19]. For patients with elevated intracranial pressure, cerebrospinal fluid diversion procedures (i.e. ventriculoperitoneal shunt or lumboperitoneal shunt) may be needed to successfully stop the egress of fluid. Lastly, some patients will have spontaneous closure of their leak.

\section{Non-Allergic Rhinitis Classification}

NAR consists of multiple entities, some of which share components of both AR and NAR. One way of further classifying these conditions distinguishes pure non-allergic rhinitis (without any component of AR), occupational rhinitis and other rhinitis syndromes. The pathogeneses of these different conditions is not clearly defined and there are many proposed mechanisms.

\section{Non-Allergic Rhinitis}

Vasomotor or idiopathic rhinitis (VMR) is the most commonly diagnosed form of NAR, accounting for $\sim 60 \%$ cases in one series [5]. VMR is characterized by sporadic or persistent nasal symptoms that are trigged by: strong smells, cold air, changes in temperature, humidity, barometric pressure, strong emotions, alcohol and changes in hormone levels. Diagnosis is made clinically and onset is typically in adulthood. Intranasal corticosteroids and intranasal antihistamines are the mainstay of therapy.

Gustatory rhinitis typically occurs after ingestion of heated foods, spicy foods or alcohol. Profuse rhinorrhea may be vagally mediated, due to a food allergy and/or other undefined mechanisms. Treatment consists of intranasal ipratropium bromide as needed.
Infectious rhinitis may be acute or chronic in nature. Symptoms include nasal congestion, mucopurulent nasal discharge, frontal headache, olfactory disturbances, postnasal drainage and cough. Viral infections account for as many as $98 \%$ of acute infectious rhinitis in young children [20]. Treatment is symptomatic, unless a bacterial cause is suspected and topical antibacterial agents can be used in some cases.

Non-allergic rhinitis with eosinophilia syndrome (NARES) usually develops in adulthood and is characterized by year round nasal symptoms such as, profuse rhinorrhea and nasal congestion. These patients have negative allergy skin testing and normal serum IgE levels. Classically, nasal smears have greater than $5 \%$ to greater than 20\% eosinophils [21]. Many of these patients may develop aspirin (ASA) sensitivity, sinusitis, nasal polyps, and asthma. These patients are also at increased risk of developing obstructive sleep apnea [22].

There is also a variant of NARES called blood eosinophilia-nonallergic rhinitis syndrome (BENARES). These patients share the same characteristics as patients with NARES except they lack nasal eosinophilia and instead have elevated serum eosinophil levels. Intranasal corticosteroids are the treatment of choice for both NARES and BENARES $[5,23]$.

\section{Occupational Rhinitis}

Occupational rhinitis can develop after exposures, typically in a work environment, and may be allergic or non allergic in nature. There are four types of occupational rhinitis. The first type is annoyance rhinitis, which is purely subjective, typically fragrance-induced, and occurs without evidence of nasal inflammation. The second type is irritant-induced rhinitis, and manifests as inflammation of the nasal mucosa without apparent immunologic or allergic basis [24].

The third type is corrosive rhinitis, following exposure to high concentrations of irritating and soluble chemical gases. Examples include ammonia and pesticides. The fourth and final type is allergic rhinitis, with evidence of an IgE mediated reaction to an occupational exposure. An example would be latex allergy in a healthcare worker. Treatment in all of these different rhinitis types consists of nasal saline to remove particulate matter, nasal corticosteroids, nasal antihistamines and avoidance. The exception is corrosive rhinitis, in which case avoidance is the only option.

\section{Other Rhinitis Syndromes}

Hormonally induced rhinitis, includes menstrual cycle related rhinitis and rhinitis of pregnancy. Rhinitis of pregnancy typically begins in the $2^{\text {nd }}$ trimester with severe congestion and resolves about 2 weeks 
postpartum [25]. Treatment consists of saline nose spray or nasal lavage. Exercise may lead to physiologic nasal vasoconstriction. External nasal dilators (e.g. strips applied to the bridge of the nose to buttress open the nares) may be effective for patients with pregnancyrelated nocturnal nasal congestion. Typically, rhinitis of pregnancy requires no specific pharmacologic intervention and intranasal glucocorticoids have not been shown to be effective. There is anecdotal evidence to support the use of nasal ipratropium and pseudoephedrine; therefore, these agents may be useful in patients who are particularly symptomatic. However, pseudoephedrine should be avoided in the first trimester of pregnancy and in women with hypertension.

Rhinitis medicamentosa is characterized by severe nasal congestion, due to a rebound effect from overuse of topical decongestants, such as oxymetazoline, an imidazole, and phenylephrine, a sympathomimetic amine. Treatment consists of topical nasal corticosteroids and/ or oral corticosteroids, with progressive withdrawal of the topical decongestant over 3-7 days. Other medications can lead to nasal symptoms as a side effect, usually congestion. Examples include ACE inhibitors, $\beta$-blockers, aspirin and NSAIDs.

Atrophic rhinitis is characterized by progressive nasal atrophy, mucosal colonization with Klebsiella ozaenae or other organisms, and a foul smelling nasal discharge. It can be seen as a post surgical complication, i.e. status post turbinectomy. Treatment consists of nasal lavage, lubrication and topical antibiotics are used for mucopurulent secretions lasting beyond 2 days. Oral antibiotics can also be used for acute infections. Surveillance rhinoscopy should be performed at least twice a year if the patient remains symptomatic [26]. The clinical presentations and treatments for non-allergic rhinitis are summarized in Table 1.

\section{Pathogenesis}

The mechanisms underlying VMR are poorly understood. Generally it is thought to arise from an imbalance of autonomic input into the nasal mucosa. An initial stimulus results in nasal congestion and/or rhinorrhea induced by tachykinins from the central nervous system, which also inhibit sympathetic mediators and thus further enhance the parasympathetic response [27,28], see Figure 3.

Tai and Baraniuk suggested that sensory C-fiber stimulation leads to release of substance P (SP) and calcitonin gene-related peptides (CGRP). This in turn leads to increased plasma excretion and glandular secretion (via acetylcholine and muscarinic receptors) manifesting as pain and stuffiness [29]. Schierhorn et al. have shown that ozone increases nasal mucosal levels of SP and neurokinin A (NKA) [30]. NKA is also known to have a similar structure and function to SP, resulting in vascular smooth muscle contraction. Therefore, sensory stimulation causes release of SP, CGRP, NKA with subsequent nasal congestion and pain.

Groneberg et al. found elevated levels of neuropeptide tyrosine (NPY), vasoactive intestinal peptide (VIP), and SP in patients with irritant rhinitis caused by cigarette smoke exposure, as compared to controls [31]. NPY is primarily distributed around blood vessels and intranasal administration of NPY has been shown to cause nasal vasoconstriction and a decrease in nitric oxide levels [32]. Noradrenaline also acts to vasoconstrict nasal mucosal blood vessels [33]. VIP is an inhibitory neurotransmitter that can cause vasodilatation and hypersecretion and thus congestion and rhinorrhea. Furthermore, Acetylcholine (Ach) release leads to glandular secretion and vasodilation [33].

The significance of the free radical, nitric oxide (NO), in the context of rhinitis has been examined. $\mathrm{NO}$ is generated by nitric oxide synthase (NOS), which requires nicotinamide adenine dinucleotide phosphate (NADPH) as a cofactor. NO is present only transiently, therefore its presence and activity are inferred by the measure of NADPH diaphorase levels in tissue, which correlate with NOS activity. In patients with VMR, epithelial damage correlates with increased NADPH diaphorase activity and thus increased NO activity. Collectively, these data suggest that NO, which has known cytotoxic effects, can cause epithelium damage. This damage could result in impaired mucociliary clearance, loss of tight junctions and basement membrane damage. This would in turn allow for increased reactivity of afferent trigeminal fibers, secretory and vascular reflexes resulting in the constellation of symptoms seen in VMR $[34,35]$.

Analysis of nasal wash protein samples have shown that the total protein and albumin concentration is higher in patients with AR as opposed to NAR and controls, who had the lowest concentrations. A $26 \mathrm{kDa}$ protein, isolated from nasal lavage, was found to be significantly elevated in patients with AR as compared to patients with NAR and controls. Although this protein is not well defined, it is believed to originate from the nasal glands because it is produced in normal subjects upon nasal provocation with pilocarpine. It is thought that this may be used to differentiate AR from NAR [36,37].

Trauma has also been implicated as a cause of VMR [38]. Studies by Giannessi et al. have shown that in patients with VMR, there was ciliary loss, absence of tight junctions, marked distension of the intercellular space, and loss of goblet cells [34].

IgE may also play a role in non-allergic rhinitis. Patients with house dust mite sensitivity by history, negative inhalant allergy skin testing and RAST (radioallergosorbent test), have been found to produce specific IgE 


\begin{tabular}{|c|c|c|}
\hline RHINITIS & CLINICAL PRESENTATION & TREATMENT \\
\hline \multicolumn{3}{|l|}{ Non-Allergic Rhinitis: } \\
\hline Vasomotor Rhinitis & $\begin{array}{l}\text { Typically adult onset, sporadic or persistent nasal symptoms } \\
\text { trigged by strong smells, cold air, changes in temperature, } \\
\text { humidity, barometric pressure, strong emotions, alcohol and } \\
\text { changes in hormone levels. }\end{array}$ & $\begin{array}{l}\text { Intranasal corticosteroids and/or intranasal antihistamines } \\
\text { are the mainstay of therapy }\end{array}$ \\
\hline Gustatory Rhinitis & $\begin{array}{l}\text { Profuse rhinorrhea after ingestion of heated foods, spicy } \\
\text { foods or alcohol. }\end{array}$ & Intranasal ipratropium bromide as needed. \\
\hline Infectious Rhinitis & $\begin{array}{l}\text { Nasal congestion, mucopurulent nasal discharge, frontal } \\
\text { headache, olfactory disturbances, postnasal drainage and } \\
\text { cough. }\end{array}$ & $\begin{array}{l}\text { Symptomatic treatment for viral infections. Topical } \\
\text { antibacterial agents, i.e. mupirocin, for suspected bacterial } \\
\text { infections. }\end{array}$ \\
\hline $\begin{array}{l}\text { Non-allergic rhinitis } \\
\text { with eosinophilia } \\
\text { syndrome (NARES) }\end{array}$ & $\begin{array}{l}\text { Typically adult onset. Individuals experience year round } \\
\text { profuse rhinorrhea and nasal congestion. These patients } \\
\text { have negative allergy skin testing and normal serum IgE } \\
\text { levels. }\end{array}$ & Intranasal corticosteroids. \\
\hline \multicolumn{3}{|l|}{$\begin{array}{l}\text { Occupational Rhinitis: } \\
\text { [54-58] }\end{array}$} \\
\hline Annoyance & $\begin{array}{l}\text { Patients report rhinitis symptoms that are purely subjective } \\
\text { after occupational exposures. Symptoms are typically } \\
\text { fragrance-induced, and occur without evidence of nasal } \\
\text { inflammation. }\end{array}$ & $\begin{array}{l}\text { Avoidance of triggers, nasal saline, nasal corticosteroids and } \\
\text { nasal antihistamines. }\end{array}$ \\
\hline Irritant & $\begin{array}{l}\text { Rhinitis symptoms after occupational exposure to irritants (e. } \\
\text { g. cigarette smoke), and these patients have objective } \\
\text { findings such as inflammation of the nasal mucosa without } \\
\text { apparent immunologic or allergic basis. }\end{array}$ & $\begin{array}{l}\text { Avoidance of triggers, nasal saline, nasal corticosteroids and } \\
\text { nasal antihistamines. }\end{array}$ \\
\hline Corrosive & $\begin{array}{l}\text { Rhinitis symptoms that occur after occupational exposure, to } \\
\text { high concentrations of irritating and soluble chemical gases } \\
\text { that in turn cause nasal inflammation which can break down } \\
\text { and ulcerate the nasal mucosa. }\end{array}$ & Avoidance of the inciting agent. \\
\hline Allergic & $\begin{array}{l}\text { Rhinitis symptoms due to an lgE mediated reaction to an } \\
\text { occupational exposure. }\end{array}$ & $\begin{array}{l}\text { Avoidance of triggers, nasal saline, nasal corticosteroids and } \\
\text { nasal antihistamines. }\end{array}$ \\
\hline \multicolumn{3}{|l|}{$\begin{array}{l}\text { Other Rhinitis } \\
\text { Syndromes: [60-63] }\end{array}$} \\
\hline $\begin{array}{l}\text { Hormonally induced } \\
\text { Rhinitis }\end{array}$ & $\begin{array}{l}\text { Includes menstrual cycle related rhinitis and rhinitis of } \\
\text { pregnancy. Rhinitis of pregnancy typically begins in the 2nd } \\
\text { trimester with severe congestion and resolves about } 2 \\
\text { weeks postpartum[25]. }\end{array}$ & $\begin{array}{l}\text { Usually requires no specific pharmacologic intervention and } \\
\text { treatment consists of saline nose spray or nasal lavage. } \\
\text { External nasal dilator may be effective for patients with } \\
\text { pregnancy-related nocturnal nasal congestion. Intranasal } \\
\text { glucocorticoids have not been shown to be effective. }\end{array}$ \\
\hline $\begin{array}{l}\text { Rhinitis } \\
\text { Medicamentosa }\end{array}$ & $\begin{array}{l}\text { Severe nasal congestion, due to a rebound effect from } \\
\text { overuse of topical decongestants, such as oxymetazoline } \\
\text { and phenylephrine. }\end{array}$ & $\begin{array}{l}\text { Topical nasal corticosteroids and/or oral corticosteroids, } \\
\text { with progressive withdrawal of the topical decongestant } \\
\text { over 3-7 days. }\end{array}$ \\
\hline
\end{tabular}

\section{Atrophic Rhinitis:}

[66-68]

Primary Atrophic

Rhinitis

Secondary Atrophic

Rhinitis
Progressive nasal atrophy, mucosal colonization with Klebsiella ozaenae or other organisms, and a foul smelling nasal discharge. It can be seen as a post surgical complication, i.e. status post turbinectomy.
Nasal lavage, lubrication and topical antibiotics are used for mucopurulent secretions lasting beyond 2 days. Oral antibiotics can also be used for acute infections. Surveillance rhinoscopy should be performed at least twice a year if the patient remains symptomatic[26].

Additional treatments for the various forms of rhinitis do exist. The most common or first line therapies are listed here.

antibodies in nasal secretions, but not in serum, upon nasal provocation with house dust mite antigen [39].

A percentage of NAR patients have been found to have increased numbers of nasal mucosal mast cells and eosinophils. These IgE expressing cells further support the role of a local allergic disease process in NAR [40,41]. Furthermore, labeled grass pollen has been shown to be bound by mast cells in patients with NAR and negative allergy inhalant testing [42]. Lastly, first line treatment is usually topical corticosteroids lending further credence to an underlying inflammatory immune mechanism.

Thromboxane A2 (TXA2) is a potent inflammatory mediator. It binds via the TXA2 receptor which is a G-protein coupled receptor. TXA2 receptor agonists have been shown to increase nasal airway resistance and nasal vascular permeability in guinea pigs [43]. Shirasaki et al. suggested that one of the isoforms of the TXA2 receptor, TP alpha may play a role in 


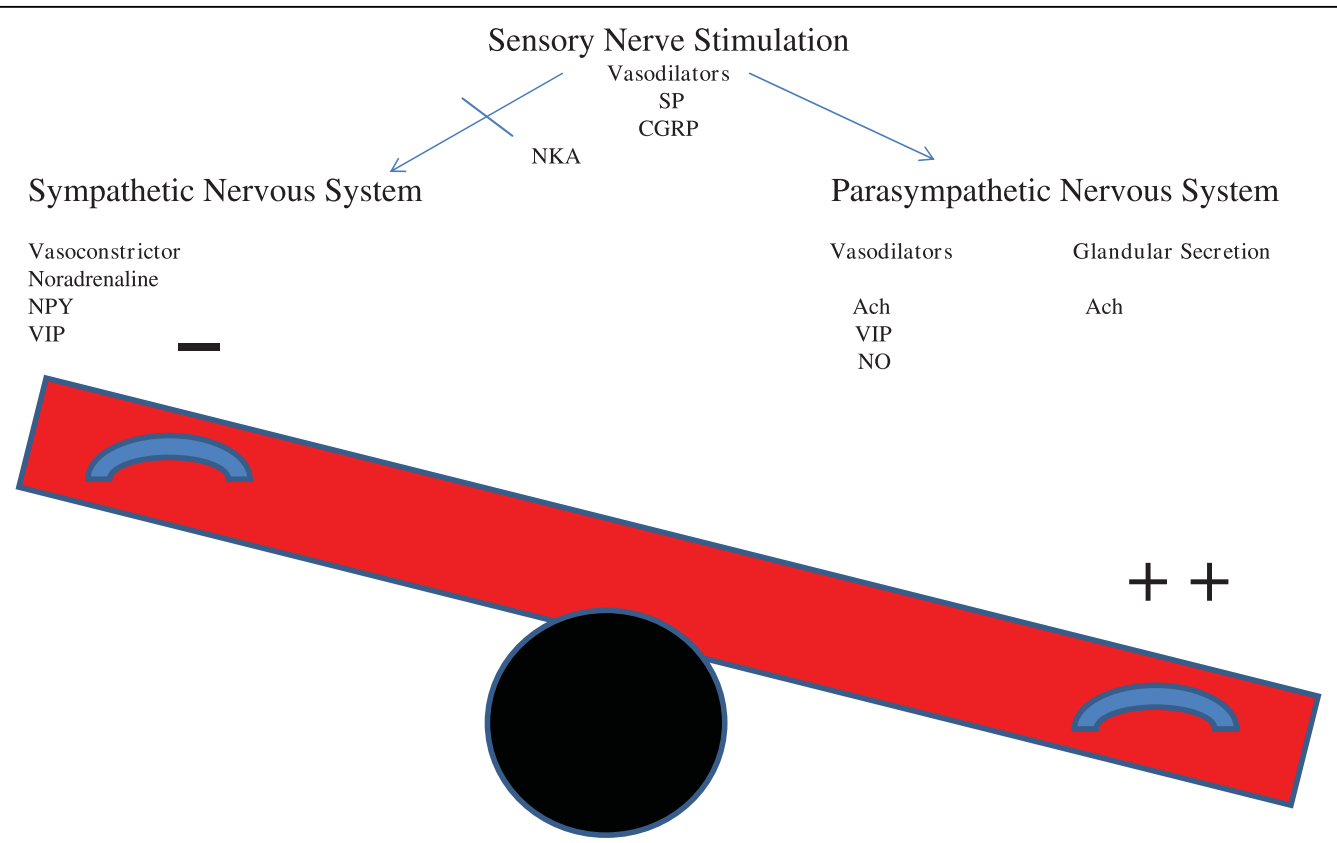

Figure 3 Balance of autonomic inputs into nasal mucosa of patients with vasomotor rhinitis (VMR). Central nervous system stimulation causes release of tachykinins, substance $P(S P)$, calcitonin gene-related peptide (CGRP) and neurokinin A (NKA) that result in inhibition of the sympathetic nervous system and shift the balance towards the parasympathetic response. Noradrenaline and neuropeptide tyrosine (NPY) cause vasoconstriction and relief of nasal congestion. Vasodilators acetylcholine (Ach), vasoactive intestinal peptide (VIP) and nitric oxide (NO) cause nasal congestion and glandular secretion [33].

allergic and non-allergic rhinitis. TP alpha expression has been found in human inferior turbinate tissue, specifically on the smooth muscle layers of the venous sinusoids, arterioles, epithelial cells and submucosal glands in human nasal mucosa from patients with AR and NAR. TXA 2 receptor antagonists have been shown to reduce allergen induced nasal mucosal swelling in patients with AR. Lastly, TXA2 receptor agonists have been shown to induce leukocyte adhesion to vascular walls, suggesting a role of TXA2 in the inflammatory cascade [44].

In patients with gustatory rhinitis, Raphael et al. have shown that increased levels of albumin and total protein (without altering the ratio of albumin to total protein), are identified in the nasal secretions of patients undergoing a food challenge. Furthermore, this effect can be blunted by intranasal atropine, suggesting that atropineinhibitable muscarinic receptors play a large role in the pathogenesis [45].

The pathogenesis of NARES is controversial and poorly understood. One theory suggests that irritants such as passive smoke exposure, induces a localized allergic inflammatory response [46]. NARES may also represent an early stage of aspirin sensitivity [47]. Lastly, there is a proposed mechanism, that eosinophils may directly damage nasal epithelial cells and lead to protracted mucociliary clearance [48-53].
The pathogenesis of occupational rhinitis is based on the etiology of the rhinitis. Annoyance rhinitis does not show any evidence of nasal mucosal inflammation. Irritant-induced rhinitis triggers include tobacco smoke exposure and symptoms are presumably due to SP release, which has been shown to trigger a neurogenic, primarily neutrophilic nasal inflammatory response $[54,55]$. The agents that cause corrosive rhinitis cause nasal inflammation which can break down and ulcerate the nasal mucosa. Lastly, allergic occupational rhinitis is IgE mediated and eosinophils, eosinophilic cationic protein, basophils and tryptase have been found in the nasal lavage fluid of these patients [56-58].

Hormonally induced rhinitis can be seen in pregnancy. It is unclear exactly how changes during pregnancy result in rhinitis. Symptoms of rhinitis may have been present prior to pregnancy but not fully appreciated [59]. An increased circulating blood volume and progesterone induced smooth muscle relaxation may lead to increased nasal mucosal blood pooling and subsequent symptoms of congestion [60]. In addition, high levels of estrogen, prolactin, VIP and/or placental growth hormone have been associated with increased nasal mucosal swelling from increased vascular leakage, glandular secretion and nasal vascular smooth muscle relaxation [61-63].

Rhinitis medicamentosa is believed to be caused not by vasodilation, but interstitial edema [64]. The 
medications responsible have been shown to cause damage to the nasal mucosa. Histologically, severe epithelial and sub epithelial damage can occur, such as loss of ciliated cells as well as gaps and ruptures of basal lamina. Furthermore, partial hyperplasia of goblet cells and proliferated seromucous glands can be seen [65].

Atrophic rhinitis is divided into primary (idiopathic) or secondary rhinitis. Primary atrophic rhinitis is characterized by nasal mucosal atrophy, dryness, crusting and a foul smelling odor $[66,67]$. The cause is unknown, but maybe associated directly or indirectly with Klebsiella ozaenae, Staphlococcus aureus, Proteus mirabilis and Escherichia coli from initial infection or secondary infection of already damaged nasal mucosa [68]. Secondary atrophic rhinitis is more commonly due to chronic sinusitis, granulomatous disease, excessive nasal turbinate surgery, trauma or irridation [68]. A summary of the proposed pathogeneses of non-allergic rhinitis is provided in Table 2.

\section{Differential Diagnosis}

As evidenced in the case presented and discussion thereafter, thorough evaluation of rhinitis is critical for proper care. There are many conditions that can mimic both allergic and non-allergic rhinitis. These conditions need to be considered in the differential diagnosis and are listed in Table 3.

\section{Concluding Remarks}

Rhinitis is a prevalent condition, resulting in direct and indirect costs in the billions of dollars. There are many causes and often the treatments overlap. However, diagnosis can often be unclear and sometimes incorrect. A thorough history and physical exam are vital, and inhalant allergy skin testing is essential to evaluate for allergic etiology.

In the case we present here, the patient's rhinorrhea was twice misdiagnosed as due to allergic rhinitis or VMR, before she sought allergy evaluation. Her CSF rhinorrhea, undiagnosed, could have resulted in serious sequelae such as meningitis and possibly death. As well, it could have been a sign of another underlying pathology such as malignancy or tumor. In her case, we believe the CSF leak was spontaneous, though it is difficult to prove whether prolonged moth ball exposure and resultant toxicity may have played some role.

Non allergic rhinitis encompasses a vast and distinct set of conditions. These conditions differ dramatically in their pathogenesis and can differ in their treatments. Evaluation of rhinitis by an allergy specialist is often necessary to establish the correct diagnosis and treatment regimen.
Table 2 Types of non-allergic rhinitis and proposed mechanisms

\begin{tabular}{|c|c|}
\hline RHINITIS & PROPOSED MECHANISM \\
\hline \multicolumn{2}{|l|}{ Non-Allergic Rhinitis: } \\
\hline Vasomotor Rhinitis & $\begin{array}{l}\text { CNS stimulation leading to } \\
\text { inhibition of the sympathetic } \\
\text { nervous system response and } \\
\text { enhancement of the } \\
\text { parasympathetic response[33]. }\end{array}$ \\
\hline Gustatory Rhinitis & $\begin{array}{l}\text { Muscarinc receptor stimulation } \\
\text { [45]. }\end{array}$ \\
\hline Infectious Rhinitis & $\begin{array}{l}\text { Typically viral or bacterial } \\
\text { induced inflammation[20]. }\end{array}$ \\
\hline $\begin{array}{l}\text { Non-allergic rhinitis with } \\
\text { eosinophilia syndrome (NARES) }\end{array}$ & $\begin{array}{l}\text { Eosinophilia leading to direct } \\
\text { nasal mucosal damage and } \\
\text { decreased mucocilliary } \\
\text { clearance[48-53]. }\end{array}$ \\
\hline
\end{tabular}

Occupational Rhinitis: [54-58]

Annoyance

Subjective without evidence of inflammation.

Irritant

Substance P induced neutrophilic inflammation.

Corrosive Agent directly damages nasal mucosa.

Allergic IgE mediated.

Other Rhinitis Syndromes: [60-63]

Hormonally induced Rhinitis

Increased circulating blood volume and possible hormonal influences (e.g. estrogen, progesterone) leading to vascular pooling and smooth muscle relaxation causing nasal congestion.

Rhinitis Medicamentosa Direct mucosal damage by alpha-adrenergic agent causing loss of ciliated cells and interstitial edema[64,65].

\begin{tabular}{cl}
\hline Atrophic Rhinitis: [66-68] & \\
Primary Atrophic Rhinitis & Infectious i.e. Klebsiella ozaenae \\
Secondary Atrophic Rhinitis & Identifiable causes: Chronic \\
& sinusitis, turbinate surgery and \\
& irradiation
\end{tabular}

Listed above are some of the proposed mechanisms for the different types of non-allergic rhinitis.

Table 3 Conditions that Mimic Rhinitis Symptoms

Nasal polyps

Anatomic abnormalities: E.g. Trauma or nasal tumors (Benign or Malignant)

Autoimmune: e.g. Sjogren syndrome, SLE, Relapsing polychondritis, Churg-Straus syndrome or Wegener granulomatosis

Metabolic: e.g. Hypothyroidism or acromegaly.

CSF Rhinorrhea

Primary Ciliary Dyskinesia

Cystic fibrosis

Immunodeficiency

Adapted from Wallace et al [21]. 


\section{Abbreviations}

(NAR): Non-allergic rhinitis; (AR): Allergic Rhinitis; (VMR): Vasomotor rhinitis; (CSF): Cerebrospinal fluid; (ICP): intracranial pressure; (NARES): Non-allergic rhinitis with eosinophilia syndrome; (BENARS): Blood eosinophilia-nonallergic rhinitis syndrome; (SP): Substance P; (CGRP): Calcitonin gene-related peptides; (VIP): Vasoactive intestinal peptide; (NPY): Neuropeptide tyrosine; (NO): Nitric oxide; (NOS): Nitric oxide synthase; (NADPH): Nicotinamide adenine dinucleotide phosphate; (NKA): Neurokinin A; (TXA2): Thromboxane A2; (RAST): Radioallergosorbent test.

\section{Author details}

${ }^{1}$ Division of Clinical Immunology, University of Tennessee Health Science Center, 50 North Dunlap St, RM 401 WPT, Memphis, TN, USA. ${ }^{2}$ Department of Neurosurgery, University of Tennessee Health Science Center, Memphis, TN, USA. ${ }^{3}$ Semmes-Murphey Neurologic and Spine Center, 6325 Humphreys Blvd, Memphis, TN, USA.

\section{Authors' contributions}

$\mathrm{CN}$ reviewed the literature and assembled the body of the text, figures, and tables. LMM reviewed the accuracy of the neurosurgical portion of this review. DBL and CM selected the topic of this manuscript and provided critical input into construction of the text, figures and tables. All of the authors shared in extensively editing the manuscript. All authors read and approved the final manuscript.

\section{Competing interests}

The authors declare that they have no competing interests.

Received: 19 November 2009

Accepted: 3 February 2010 Published: 3 February 2010

\section{References}

1. Schoenwetter WF, Dupclay L Jr, Appajosyula S, Botteman MF, Pashos CL: Economic impact and quality-of-life burden of allergic rhinitis. Curr Med Res Opin 2004, 20:305-17.

2. Settipane RA, Charnock DR: Epidemiology of rhinitis: allergic and nonallergic. Clin Allergy Immunol 2007, 19:23-34.

3. Sibbald B, Rink E: Epidemiology of seasonal and perennial rhinitis: clinical presentation and medical history. Thorax 1991, 46:895.

4. Settipane RA: Rhinitis: a dose of epidemiological reality. Allergy Asthma Proc 2003, 24:147-154.

5. Settipane RA, Lieberman P: Update on non-allergic rhinitis. Ann Allergy Asthma Immunol 2001, 86:494-507.

6. Togias A: Age relationships and clinical features of nonallergic rhinitis. Allergy Clin Immunol 1990, 85:182.

7. Middleton E Jr: Chronic rhinitis in adults. J Allergy Clin Immunol 1988, 81:971.

8. Martin TJ, Loehrl TA: Endoscopic CSF leak repair. Curr Opin Otolaryngol Head Neck Surg 2007, 15:35-59.

9. Lopatin AS, Kapitanov DN, Potapov AA: Endonasal endoscopic repair of spontaneous cerebrospinal fluid leaks. Arch Otol 2003, 129:859-862.

10. Schlosser RJ, Bolger WE: Nasal cerebrospinal fluid leaks: critical review and surgical considerations. Laryngoscope 2004, 114:255-265.

11. Wise SK, Schlosser RJ: Evaluation of spontaneous nasal cerebrospinal fluid leaks. Curr Opin Otolaryngol Head Neck Surg 2007, 15:28-34.

12. Stone JA, Castillo M, Neelon B, Mukherji SK: Evaluation of CSF leaks: high resolution $\mathrm{CT}$ compared with contrast-enhanced $\mathrm{CT}$ and radionuclide cisternography. AJNR Am J Neuroradiol 1999, 20:706-712.

13. Sillers MJ, Morgan E, El Gammal T: Magnetic resonance cisternography and thin coronal computerized tomography in the evaluation of cerebrospinal fluid rhinorrhea. Am J Rhinol 1997, 11:387-392.

14. Schlosser RJ, Bolger WE: Nasal cerebrospinal fluid leaks: critical review and surgical considerations. Laryngoscope 2004, 114:255-265.

15. Ohnishi T: Bony defects and dehiscences in the roof of ethmoid cells. Rhinology 1981, 19:195-202.

16. Shetty PG, Shroff MM, Fatterpekar GM, Sahani DV, Kirtane MV: A retrospective analysis of spontaneous sphenoid sinus fistula: MR and CT findings. AJNR Am J Neuroradiol 2000, 21:337-342.

17. Lanza DC, O'Brien DA, Kennedy DW: Endoscopic repair of cerebrospinal fluid fistulae and encephaloceles. Laryngoscope 1996, 106:1119-1125.
18. Schick B, lbing R, Brors D, Draf W: Long-term study of endonasal duraplasty and review of the literature. Ann Otol Rhinol Laryngol 2001, 110:142-147.

19. Schlosser RJ, Bolger WE: Nasal cerebrospinal fluid leaks: critical review and surgical considerations. Laryngoscope 2004, 114:255-265.

20. Dykewicz MS, Fineman S, Skoner DP, Nicklas R, Lee R, Blessing-Moore J, Li JT, Bernstein IL, Berger W, Spector S, Schuller D: Diagnosis and management of rhinitis: complete guidelines of the Joint Task Force on Practice Parameters In Allergy, Asthma, and Immunology. American Academy of Allergy, Asthma, and Immunology. Ann Allergy Asthma Immunol 1998, 81:478.

21. Wallace DV, Dykewicz MS, Bernstein DI, Blessing-Moore J, Cox L, Khan DA, Lang DM, Nicklas RA, Oppenheimer J, Portnoy JM, Randolph CC, Schuller D, Spector SL, Tilles SA: Joint Task Force on Practice; American Academy of Allergy; Asthma \& Immunology; American College of Allergy; Asthma and Immunology; Joint Council of Allergy, Asthma and Immunology. The diagnosis and management of rhinitis: an updated practice parameter. J Allergy Clin Immunol 2008, 122(2 Suppl):S1-84.

22. Kramer MF, de la Chaux R, Fintelmann R, Rasp G: NARES: a risk factor for obstructive sleep apnea?. Am J Otolaryngol 2004, 25:173-7.

23. Mullarkey MF, Hill JS, Webb DR: Allergic and nonallergic rhinitis: their characteristics with attention to the meaning of nasal eosinophilia. J Allergy Clin Immunol 1980, 65:122.

24. Bardana EJ: Occupational asthma and related respiratory disorders. Dis Mon 1995, 41:143-199.

25. Ellegard E, Karlsson G: Nasal congestion during pregnancy. Clin Otolaryngol Allied Sci 1999, 24:307-11.

26. Stringer S, DeShazo R: Atrophic Rhinitis. Up to Date 2009.

27. Jaradeh SS, Smith TL, Torrico L, Prieto TE, Loehrl TA, Darling RJ, Toohill RJ: Autonomic nervous system evaluation of patients with vasomotor rhinitis. Laryngoscope 2000, 110:1828-1831.

28. Loehrl TA, Smith TL, Darling RJ, Torrico L, Prieto TE, Shaker R, Toohill RJ, Jaradeh SS: Autonomic dysfunction, vasomotor rhinitis, and extraesophageal manifestations of gastroesophageal reflux. Otolaryngol Head Neck Surg 2002, 126:382-387.

29. Tai CF, Baraniuk JN: Upper airway neurogenic mechanisms. Curr Opin Allergy Clin Immunol 2002, 2:11-19.

30. Schierhorn K, Hanf G, Fischer A, Umland B, Olze H, Kunkel G: Ozoneinduced release of neuropeptides from human nasal mucosa cells. Int Arch Allergy Immunol 2002, 129:145-151.

31. Groneberg DA, Heppt W, Cryer A, Wussow A, Peiser C, Zweng M, Dinh QT, Witt $C$, Fischer A: Toxic rhinitis-induced changes of human nasal mucosa innervation. Toxicol Pathol 2003, 31:326-331.

32. Tosun F, Sezen I, Gerek M, Ozkaptan Y, Yapar M, Calişkaner Z, Akman S: Electrophoretic evaluation of nasal discharge in patients with allergic rhinitis and vasomotor rhinitis. Am J Rhinol 2002, 16:141-144.

33. Salib RJ, Harries PG, Nair SB, Howarth PH: Mechanisms and mediators of nasal symptoms in non-allergic rhinitis. Clin Exp Allergy 2008, 38:393-404.

34. Giannessi F, Fattori B, Ursino F, Giambelluca MA, Soldani P, Scavuzzo MC, Ruffoli R: Ultrastructural and ultracytochemical study of human nasal respiratory epithelium in vasomotor rhinitis. Acta Otolaryngol 2003, 123:943-949.

35. Ruffoli R, Fattori B, Giambelluca MA, Soldani P, Giannessi F: Ultracytochemical localization of the NADPH-d activity in the human nasal respiratory mucosa in vasomotor rhinitis. Laryngoscope 2000, 110:1361-1365.

36. Iguchi Y, Yao K, Okamoto M: A characteristic protein in nasal discharge differentiating non-allergic chronic rhinosinusitis from allergic rhinitis. Rhinology 2002, 40:13-17.

37. Tosun F, Sezen I, Gerek M, Ozkaptan Y, Yapar M, Calişkaner Z, Akman S: Electrophoretic evaluation of nasal discharge in patients with allergic rhinitis and vasomotor rhinitis. Am J Rhinol 2002, 16:141-144.

38. Segal S, Shlamkovitch N, Eviatar E, Berenholz L, Sarfaty S, Kessler A: Vasomotor rhinitis following trauma to the nose. Ann Otol Rhinol Laryngol 1999, 108:208-210.

39. Huggins K, Brostoff J: Local production of specific lgE antibodies in allergic rhinitis patients with negative skin tests. Lancet 1975, 2:148.

40. Powe DG, Huskisson R, Carney A, Jenkins D, Jones NS: Evidence for an inflammatory pathophysiology in idiopathic rhinitis. Clin Exp Allergy 2001, 31:864-72. 
41. Berger G, Goldberg A, Ophir D: The inferior turbinate mast cell population of patients with perennial allergic and nonallergic rhinitis. Am J Rhinol 1997, 11:63-6

42. Powe DG, Jagger C, Kleinjan A, Carney AS, Jenkins D, Jones NS: 'Entopy': localised mucosal allergic disease in the absence of systemic responses for atopy. Clin Exp Allergy 2003, 33:1374-9.

43. Yamasaki M, Matsumoto T, Fukuda S, Nakayama T, Nagaya H, Ashida Y: Involvement of thromboxane A2 and histamine in experimental allergic rhinitis of guinea pigs. J Phamacol Exp Ther 1997, 280:1471-1479.

44. Shirasaki H, Kikuchi M, Seki N, Kanaizumi E, Watanabe K, Himi T: Expression and localization of the thromboxane $A_{2}$ receptor in human nasal mucosa. Prostaglandins Leukot Essent Fat Acids 2007, 76:315-320.

45. Raphael G, Raphael MH, Kaliner M: Gustatory rhinitis: a syndrome of foodinduced rhinorrhea. J Allergy Clin Immunol 1989, 83(1):110-5.

46. Villar MT, Holgate ST: IgE, smoking and lung function. Clin Exp Allergy 1995, 25:206-209.

47. Moneret-Vautrin DA, Hsieh V, Wayoff M, Guyot JL, Mouton C, Maria Y: Nonallergic rhinitis with eosinophilia syndrome a precursor of the triad: nasal polyposis, intrinsic asthma, and intolerance to aspirin. Ann Allergy 1990, 64:513-518.

48. Bousquet J, Chanez P, Lacoste JY, et al: Eosinophilic inflammation in asthma. N Engl J Med 1990, 323:1033-1039.

49. Hastie AT, Loegering DA, Gleich GJ, Kueppers F: The effect of purified human eosinophil major basic protein on mammalian ciliary activity. Am Rev Respir Dis 1987, 135:848-853.

50. Flavahan NA, Slifman NR, Gleich GJ, Vanhoutte PM: Human eosinophil major basic protein causes hyperreactivity of respiratory smooth muscle. Am Rev Respir Dis 1988, 138:685-688.

51. Venge P, Dahl R, Fredens K, Peterson CG: Epithelial injury by human eosinophils. Am Rev Respir Dis 1988, 138:S54-S57.

52. Spector SL, English G, Jones L: Clinical and nasal biopsy response to treatment of perennial rhinitis. J Allergy Clin Immunol 1980, 66:129-137.

53. Ayars GH, Altman LC, McManus MM, Agosti JM, Baker C, Luchtel DL, Loegering DA, Gleich GJ: Injurious effect of the eosinophil peroxidehydrogen peroxidehalide system and major basic protein on human nasal epithelium in vitro. Am Rev Respir Dis 1989, 140:125-131.

54. Nieber K, Baumgarten C, Witzel A, Rathsack R: The possible role of substance $\mathrm{P}$ in the allergic reaction, based on two different provocation models. Arch Allergy Appl Immunol 1991, 94:334-338.

55. Graham D, Henderson F, House D: Neutrophil influx measured in nasal lavages of humans exposed to ozone. Arch Environ Health 1988, 43:228-33.

56. Krakowiak A, Ruta U, Gorski P, Kowalska S, Palczynski C: Nasal lavage fluid examination and rhinomanometry in the diagnostics of occupational airway allergy to laboratory animals. Int J Occup Med Environ Health 2003, 16:125-32.

57. Gorski P, Krakowiak A, Ruta U: Nasal and bronchial responses to flourinhalation in subjects with occupationally induced allergy affecting the airway. Int Arch Occup Environ Health 2000, 73:488-97.

58. Palczynski C, Walusiak J, Ruta U, Gorski P: Nasal provocation test in the diagnosis of natural rubber latex allergy. Allergy 2000, 55:34-41.

59. Incaudo GA, Schatz M: Rhinosinusitis associated with endocrine conditions: hypothyroidism and pregnancy. Nasal Manifestations of Systemic Diseases Providence Ocean Side PublicationsSchatz M, Zeiger RS, Settipane GA 1991, 54:49-67.

60. Toppozada H, Michaels L, Toppozada M, El-Ghazzawi I, Talaat M, Elwany S: The human respiratory nasal mucosa in pregnancy. An electron microscopic and histochemical study. J Laryngol Otol 1982, 96:613-626.

61. Ellegard E, Karlsson G: Nasal congestion during pregnancy. Clin Otolaryngol Allied Sci 1999, 24:307-11.

62. Blaiss MS: Management of rhinitis and asthma in pregnancy. Ann Allergy Asthma Immunol 2003, 90:16-22.

63. Ellegard E, Oscarsson J, Bougoussa M, Igout A, Hennen G, Eden S, Karlsson G: Serum level of placental growth hormone is raised in pregnancy rhinitis. Arch Otolaryngol Head Neck Surg 1998, 124:439-43.

64. Graf $\mathrm{P}$, Hallen H, Juto JE: The pathophysiology and treatment of rhinitis medicamentosa. Clin Otolaryngol 1995, 20:224-229.

65. Knipping S, Holzhausen HJ, Goetze G, Riederer A, Bloching MB: Rhinitis medicamentosa: electron microscopic changes of human nasal mucosa. Otolaryngol Head Neck Surg 2007, 136:57-61.
66. Zohar Y, Talmi YP, Strauss M, Finkelstein Y, Shvilli Y: Ozena revisited. J Otolaryngol 1990, 19:345-9.

67. Bunnag C, Jareoncharsri P, Tansuriyawong P, Bhothisuwan W, Chantarakul N: Characteristics of atrophic rhinitis in Thai patients at the Siriraj Hospital. Rhinology 1999, 37:125-30.

68. Moore EJ, Kern EB: Atrophic rhinitis: a review of 242 cases. Am J Rhinol $2001,15: 355-61$

doi:10.1186/1476-7961-8-1

Cite this article as: Nozad et al:: Non-allergic rhinitis: a case report and review. Clinical and Molecular Allergy 2010 8:1.

\section{Submit your next manuscript to BioMed Central and take full advantage of:}

- Convenient online submission

- Thorough peer review

- No space constraints or color figure charges

- Immediate publication on acceptance

- Inclusion in PubMed, CAS, Scopus and Google Scholar

- Research which is freely available for redistribution

Submit your manuscript at www.biomedcentral.com/submit
C Biomed Central 